Sex Discrimination

and the Law in Hawaii 



\section{Sex Discrimination}

and the Law in Hawaii

\section{A GUIDE TO YOUR LEGAL RIGHTS}

written and edited by Judith R. Gething

The University Press of Hawaii Honolulu 
Copyright @ 1979 by The University Press of Hawaii

All rights reserved. No part of this work may be reproduced or transmitted in any form or by any means, electronic or mechanical, including photocopying and recording, or by any information storage or retrieval system, without permission in writing from the publisher.

Manufactured in the United States of America

\section{Lbrary of Congress Cataloging in Publication Data}

Gething, Judith R., 1940

Sex discrimination and the law in Hawaii.

Includes bibliographical references and index.

1. Sex discrimination-Law and legislation-

Hawaii. 2. Sex discrimination against women-

Law and legislation-Hawaii. I. Title.

KFH411.7.G47 342'.969'087 78-10636

ISBN 0-8248-0620-4 